\section{Who will do an ERCP on me when I'm retired?}

To the Editor: In South Africa (SA) it is widely accepted that subspecialties such as gastroenterology (GE) are not functioning adequately, ${ }^{[1]}$ as was highlighted in the SAMJ in 2004. ${ }^{[2]}$ Fewer trainees are able to choose to subspecialise in GE. Indeed, all specialties are faced with a lack of training facilities.

The National Department of Health $(\mathrm{NDoH})$ plans to run the academic hospitals, wherein specialist and subspecialist training are undertaken. ${ }^{[3]}$ At present, provincial DoHs create registrar positions for training. The current focus on general specialties is understandable, given the medical human resources shortages in SA, but it needs to be stated that if there are no/insufficient posts created for subspecialisation locally, doctors will emigrate ${ }^{[4-7]}$ and many developed countries would welcome them. ${ }^{[8]}$ Improved career opportunities are important to stop this exodus.

We worry that subspecialists are being considered a 'luxury. There are glaring disparities between SA and developed countries, e.g. in SA there is 1 gastroenterologist per 1000000 population, while in Europe the number of gastroenterologists varies between $1 / 5000$ and $1 / 50000 .^{[1,9]}$ GE encompasses the clinical management of peptic ulcer disease, inflammatory bowel disease, (viral) hepatitis and other liver disease, parasitic infections, celiac disease and gastrointestinal (GI) cancer. Such endoscopy units as there are in the public sector lack state-ofthe-art equipment. A so-called 'capital works' programme has been implemented to build new clinics to improve the GE infrastructure, but a trained workforce to man these, with only 62 gastroenterologists available in our hospitals, is the problem. ${ }^{[1]}$ Owing to this shortage, gastroenterologists currently in their mid-60s ask, "Who will do an endoscopic retrograde cholangiopancreatography (ERCP) on me when I'm retired?'

Subspecialty societies and associations should inform the public about these looming manpower problems. An obvious solution is partnership between the public and private sectors to facilitate subspecialty training and the establishment of training programmes outside the academic hospitals $s^{[1,7]}$ provided there is adequate regulation and supervision. The potential 'brain-drain' of doctors seeking to subspecialise abroad would thus be avoided.

Training in GE has two components: endoscopy, and the clinical management of patients with GI and liver diseases. Private facilities, in close cooperation with academic hospitals, would work to define these training programmes. GE might provide a template for other (sub)specialties.

Endoscopy training should be structured. The clinical component could take place during placements in centres able to deliver quality training as assessed by a regulatory body applying agreed standards. Trainees would be signed off if deemed competent by their trainers. All trainees would continue to undergo knowledge-based examination such as the SA, US or UK Specialist Certificate Exam - to confirm their attainment of an acceptable standard of theoretical knowledge.

We hope to organise such training of adequate numbers of gastroenterologists to serve both the public and private sector, if possible, as part of a new master plan to be implemented this year for specialty and subspecialty training, in consultation with Minister Aaron Motsoaledi (NDoH).

\section{Chris Ziady}

Gastroenterology, Kloof Medical Centre, Pretoria

chrisziady@mweb.co.za

\section{Robert Bond}

Gastroenterology, Unitas Hospital, Pretoria

\section{Chuka Nwokolo}

Gastroenterology, Warwick Medical School, University of Warwick, UK and European Board of Gastroenterology and Hepatology (European Curriculum 2012)

\section{Chris J J Mulder}

Gastroenterology, VU Medical University Centre, Amsterdam, the Netherlands and European Board of Gastroenterology and Hepatology (European Curriculum 2012)

1. Mulder CJ, Puri AS, Reddy DN. Gastroenterology training in private hospitals: India vs South Africa. World J Gastroenterol 2010;16(8):948-952.

2. Thomson SR. SAGES report on academic gastro-intestinal unit survey. S Afr Med J 2004;94(11):894-895. 3. Mapumulo Z. Plan to centralise teaching hospitals. City Press. 6 January 2013. http://www.citypress. co.za/news/plan-to-centralise-teaching-hospitals/

4. Erasmus N Shaves of the state - medical internship and community service in South Africa. S Afr Med J 2012;102(8):655-658. [http://dx.doi.org/10.7196/samj.5987]

Reed G, Torres MS. Training and retaining more rural doctors for South Africa. MEDICC Review 2008;10(1):49-51

6. de Villiers M, De Villiers PJT. Doctor's view of working conditions in the rural hospitals in the Western Cape. SA Fam Pract 2004;46:21-26.

7. Mandeville KL, Krabshuis J, Ladep NG, Mulder CJ, Quigley EM, Khan SA. Gastroenterology in developing countries: Issues and advances. World J Gastroenterol 2009;15(23):2839-2854.

8. Mullan F. The metrics of the physician brain drain. N Engl J Med 2005;353(17):1810-1818. [http://dx.doi org/10.1056/NEJMsa050004

9. van Turenhout ST, Terhaar sive Droste JS, Meijer GA, Masclée AA, Mulder CJ. Anticipating implementation of colorectal cancer screening in The Netherlands: A nation wide survey on endoscopic supply and demand. BMC Cancer 2012;12:46. [http://dx.doi.org/10.1186/1471-2407-12-46]

S Afr Med J 2013;103(7):435. DOI: 10.7196/SAMJ.6928 